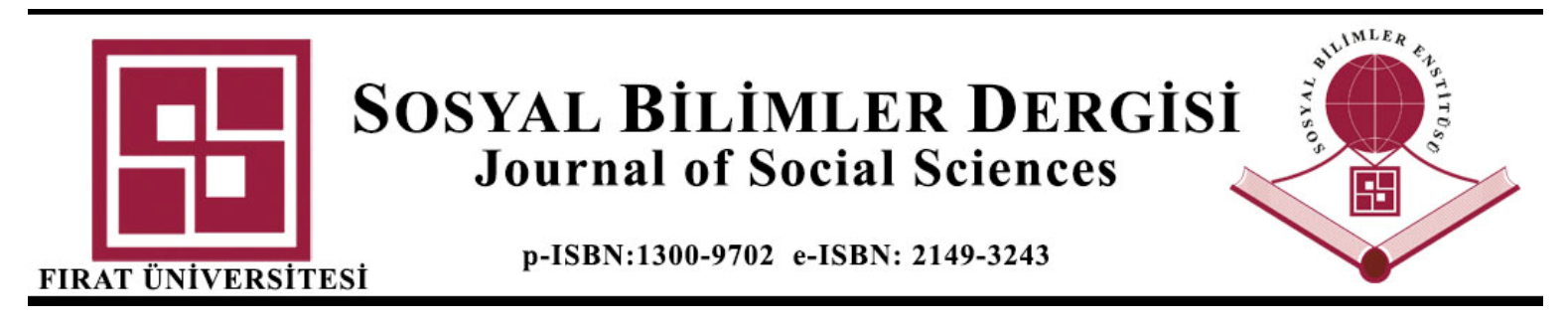

\title{
HEMAVEND AŞİRETI' NIIN TÜTÜN KAÇAKÇILIĞI İDDİALARI VE ADANA REJİ İDARESİ
}

\section{Alleged Tobacco Smuggling of The Hemavend Trible And Adana Rejı Admınıstratıon}

\author{
Mustafa DAĞ $\breve{1}^{1}$ \\ ${ }^{1}$ Harran Üniversitesi, Fen Edebiyat Fakültesi, Tarih Bölümü, Şanlıurfa, mustafadag@harran.edu.tr, orcid.org/0000- \\ 0003-4571-8115
}

Araştırma Makalesi/Research Article

\author{
Makale Bilgisi \\ Geliş/Received: \\ 16.06.2021 \\ Kabul/Accepted: \\ 11.08 .2021
}

DOI:

10.18069/firatsbed.953446

Anahtar Kelimeler Reji İdaresi, Adana Reji İdaresi, Hemavend Aşireti, tütün, kaçakçılık.

\begin{abstract}
ÖZ
Bu çalışmada, 19. Yüzyılda Adana Reji İdaresi döneminde bölgede Hemavend Aşireti'nin tütün kaçakçılığı ile ilgili iddiaları değerlendirilmiştir. Osmanlı İmparatorluğu, geniş sınırlara sahip olmanın yanı sıra verimli arazilere, pek çok limana, önemli ticaret güzergâhlarına ve geniş bir ticaret pazarına sahip olmasından dolayı kaçakçılık olgusu devlet yöneticilerini meşgul eden bir sorun olarak karşımıza çıkmıştır. Bu durum İmparatorluğun yabancı devletler ile olan ticaretini etkilediği gibi yerel ticareti de etkilemiştir. XIX. Yüzyılda Osmanlı İmparatorluğu'nda yaşanan bu durumun bir örneği Adana Reji İdaresi'nde meydana gelmiştir. Osmanlı İmparatorluğu'nda meydana gelen kaçakçıllk faaliyetlerinin pek çok nedeni vardır. Ancak bizim bu çalışmadaki amacımız, Hemavend Aşireti'nin XIX. Yüzyılın ortalarından itibaren Adana vilayetine yerleşmeleriyle birlikte vilayet genelinde ekonomik sıkıntıların yanı sıra bölgede kaçakçılık faaliyetlerin neden olduğu asayiş sorunlarını tespit etmeye çalışmaktır. $\mathrm{Bu}$ bağlamda özellikle vilayet genelinde Hemavend Aşireti'nin tütün kaçakçıllğı iddiaları üzerinde durmaktır. Bilhassa Hemavendlilerin Adana'ya yerleşme süreçleri, bölgedeki kaçakçılık faaliyetleri ve bu tür girişimlerin önlenmesi amacıyla alınan önlemler ele alınmaya çalışlacaktır. Bu çerçevede Adana Reji İdaresi, kaçakçılık ve Hemavend Aşireti'nin faaliyetlerine dair bu çalışmada arşiv belgelerinden ve vilayet salnamelerinden istifade edilmiştir.
\end{abstract}

Keywords

Regie Administration,

Adana Regie

\section{ABSTRACT}

In this study, the claims of the Hemavend Tribe about tobacco smuggling in the region during the Adana Regime Administration in the 19th century were evaluated. Since the Ottoman Empire had fertile lands, many ports, important trade routes and a wide trade market, in addition Administration, Hemavend Tribe, tobacco, contraband. state administrators. This situation not only affected the Empire's trade with foreign states, but also affected local trade. XIX. An example of this situation in the Ottoman Empire in the 19th century occurred in the Adana Reji Administration. There are many reasons for smuggling activities in the Ottoman Empire. However, our aim in this study is that Hemavend Tribe XIX. It is to try to determine the security problems caused by smuggling activities in the region as well as the economic problems throughout the province with the settlement of Adana Province since the middle of the century. In this context, it is especially focused on the tobacco smuggling allegations of the Hemavend Tribe throughout the province. In particular, the process of settlement of Hemavendians in Adana, smuggling activities in the region and the measures taken to prevent such attempts will be discussed. In this context, in this study on Adana Regiment Administration, smuggling and the activities of the Hemavend Tribe It has been prepared by making use of archive documents and provincial yearbooks.

Atıf/Citation: DAĞ, M. (2021). Hemavend Aşireti’nin Tütün Kaçakçıllı̆̆ İddiaları ve Adana Reji İdaresi, Fırat Üniversitesi Sosyal Bilimler Dergisi, 31, 3 (1333-1344).

Sorumlu Yazar/Corresponding autohor: Mustafa DAĞ, mustafadag@harran.edu.tr 


\section{Giriş}

Günümüzde dünya üzerinde 120 farklı ülkede üretimi yapılan tütünün geçmişi 8 bin yıl öncesine kadar dayanmaktadır. 1492 yılına kadar yalnızca Amerika kıtasının yerli halkı tarafından kullanılan tütün, Christoper Colombus'un Amerika kıtasını keşfetmesi neticesinde tanınarak Avrupa kıtasına taşınmışıı. Amerika'nın yerlileri tarafından tobbaco olarak nitelendirilen tütün hızlı şekilde kıtalar arası yayılış gösterdikten sonra 1598 yılında Osmanlı İmparatorluğu'na giriş yapmıştır. İmparatorlukta ilk tütün ekimi ise 1604 y1lında Rumeli bölgesinde yapılmıştır (Ösen, 2015, s. 38; Yılgür, 2015, s. 145-146; Aslan, 2005, s. 19; Gökdemir, 1994, s. 12). Tütünün imparatorluk sınırları içerisinde tüketiminin hızlı bir şekilde artış göstermesine bağlı olarak imparatorluk için önemli bir gelir kalemi durumuna gelmiştir. Her ne kadar 1609-1649 yılları arasında tütün alanında yasaklayıcı politika izlenmişse de 1688 yılında yapılan düzenlemeyle birlikte öşür vergisi dışında tütün ticareti de vergiye tabi tutularak ilk defa devlet tütün ticaretinden gelir elde etmeye başlamıştır. 1691 yılında nısıf vergisi alınmaya başlanmıştır. Nizam-ı Cedid sslahatlarıyla birlikte ise Duhan Gümrükleri mukataaları İrad-1 Cedid Hazinesine aktarılmışıı (Yardımcı, 2017, s. 32, 33, 50; Baydilli, 2007, s. 175-178). 1872 yılına kadar tütün vergileri Gümrük Emaneti tarafından idare edilmiştir. 1872 ile 1873 yılları arasında tütün imtiyazı Mösyö Zarifi ve Hıristaki Efendiye verilmiştir. 1873 ile 1879 yılları arasında tütünde Devlet İnhisarı İdaresi dönemi uygulanmıştır (Yurtoğlu, 2018, s. 83; Gürdamar, 2019, s. 18-19). 1879 ile 1881 yılları arasında Rüsum-ı Sitte İdaresi tarafından denetim altına alınan tütün, (BOA, HR. ID, 290/50, 10 Aralık 1879; BOA, Y. A. RES, 4/70, 22 Kasım 1879) 1881 ile 1883 yılları arasında Düyun-ı Umumiye İdaresi'nin imtiyazına girmiştir (Keskinkılıç, 1997, s. 73; Gündüz, 2012, s. 8).

Düyun-ı Umumiye İdaresi'ni kuran alacaklı devletler borçlarını tahsil etmek amacıyla imtiyazını almış oldukları tütün alanında istenilen başarıyı elde edememişlerdir. İstenilen başarının elde edilememesinin önemli nedenleri arasında kaçakçılık faaliyetleri yer almıştır. Bu nedenden dolayı Muharrem Kararnamesine dayanılarak tütünün imtiyaz hakkı $30^{1}$ yıllığına kurulacak olan Reji İdaresi'ne devretme kararı alınmışııı (Özcan, 2011, s. 129-130). Bu bağlamda 1883 yılında Osmanlı İmparatorluğu sınırları içerisinde ekimi, ticareti ve tüketimi yapılan tütünün ${ }^{2}$ denetimi için sermayesi ve idaresi yabancıların elinde olan Reji İdaresi ${ }^{3}$ kurulmuştur (BOA, HR. İD, 304/31, 26 Aralık 1882; BOA, HR. ID, 304/33, 26 Aralık 1882; BOA, DR. ID, 304/34, 26 Aralık 1882). İdare kısa süre içerisinde imparatorluğun genelinde açmış olduğu şubeler ve yapmış olduğu atamalar aracılığı ile teşkilatlanmasını sağlamaya çalışmıştır (Gökdemir, 1993, s. 326-328). Reji İdaresi'nin oluşumu, çalışması, hukuki durumu ile idareye tanınmış olan yetki ve hakları 28 Mayıs 1883 tarihinde hazırlanmış olan şartnamede açıkça belirtilmiştir (BOA, A.) MKT. MHM, 560/6, 27 Temmuz 1893; BOA, A.) DVN. MKL, 82/2, 19 Şubat 1912). İdarenin işleyişi ve hakları hakkında bilgi veren şartname 29 maddeden oluşmaktadır (BOA, HR. HMŞ. İŞO, 166/31, 10 Şubat 1884). İdareye tütünü işletme imtiyazı olarak 30 yıllık süre tanınmıştır. Ancak bu sürenin dolmasıyla birlikte tarafların anlaşması neticesinde bu sürenin uzatılabileceği de belirtilmiştir (Dığıroğlu, 2007, s. 32). Nitekim 15 Nisan 1914 tarihinde 30 yıllık imtiyaz süresinin sona ermesinden dolayı bu sürenin 15 yıl daha uzatıldığı tespit edilmiştir (Keskinkılıç, 1978, s. 151152; Parvus Efendi, 1997, s. 66). Reji İdaresi başta Fransa ve Almanya devletleri olmak üzere yabancı sermeye ile kurularak idare edilmiştir. (Pamuk, 2019, s. 122). İdaresi yabancıların elinde olan bu kuruluş teşkilatlanmaya önem göstererek bir yıl içerisinde diğer vilayetlerde olduğu gibi Adana vilayetinde de teşkilatlanmasını sağlamıştır. Daha önceleri 1880 yılında inşa edildiği düşünülen ve Düyun-u Umumiye Ídaresi ${ }^{4}$ binası olarak kullanılan iki katlı yapının 1883 yılında idare için tahsis edildiği bilgisine ulaşılmıştır (Yurtsever, 2017, s. 154-156. (Foto 1); Özüdoğru, 2010, s. 79).

\footnotetext{
${ }^{1} 1914$ yılında 30 yıllık imtiyaz süresinin bitmesiyle birlikte yapılan antlaşma gereği imtiyaz süresi 15 yıl daha uzatılarak 1923 yılına kadar idare görevine devam etmiştir (BOA, MV, 165/11, 19 Mayıs 1912; BOA, BEO, 4219/316355, 4 Ekim 1913).

2 Tobbaco veya nicotiana tabacum olarak isimlendirilen tütün 1492 y1lında Amerika kıtasında yerli halk tarafından kullanılırken Christoper Colombus tarafından keşfedilmiş̧ir (Kültüral ve Giannopoulos, 2021, s. 16; Yılgür, 2015, s. 145146).

3 Tam adı “Memalik-i Şahane Duhanları Müşterekül Menfaa Reji İdaresi” olarak bilinmektedir (Balkan, 2011, s. 80).

41881 yılında Muharrem Kararnamesinden sonra Avrupalı alacaklı devletler tarafından borçlarını tahsil etmek amacıyla mali anlamda görev yapmak üzere kurulmuştur (Pamuk, 2018, s. 55; Pamuk, 2018: 130; Üner, 2011, s. 288-289).
} 


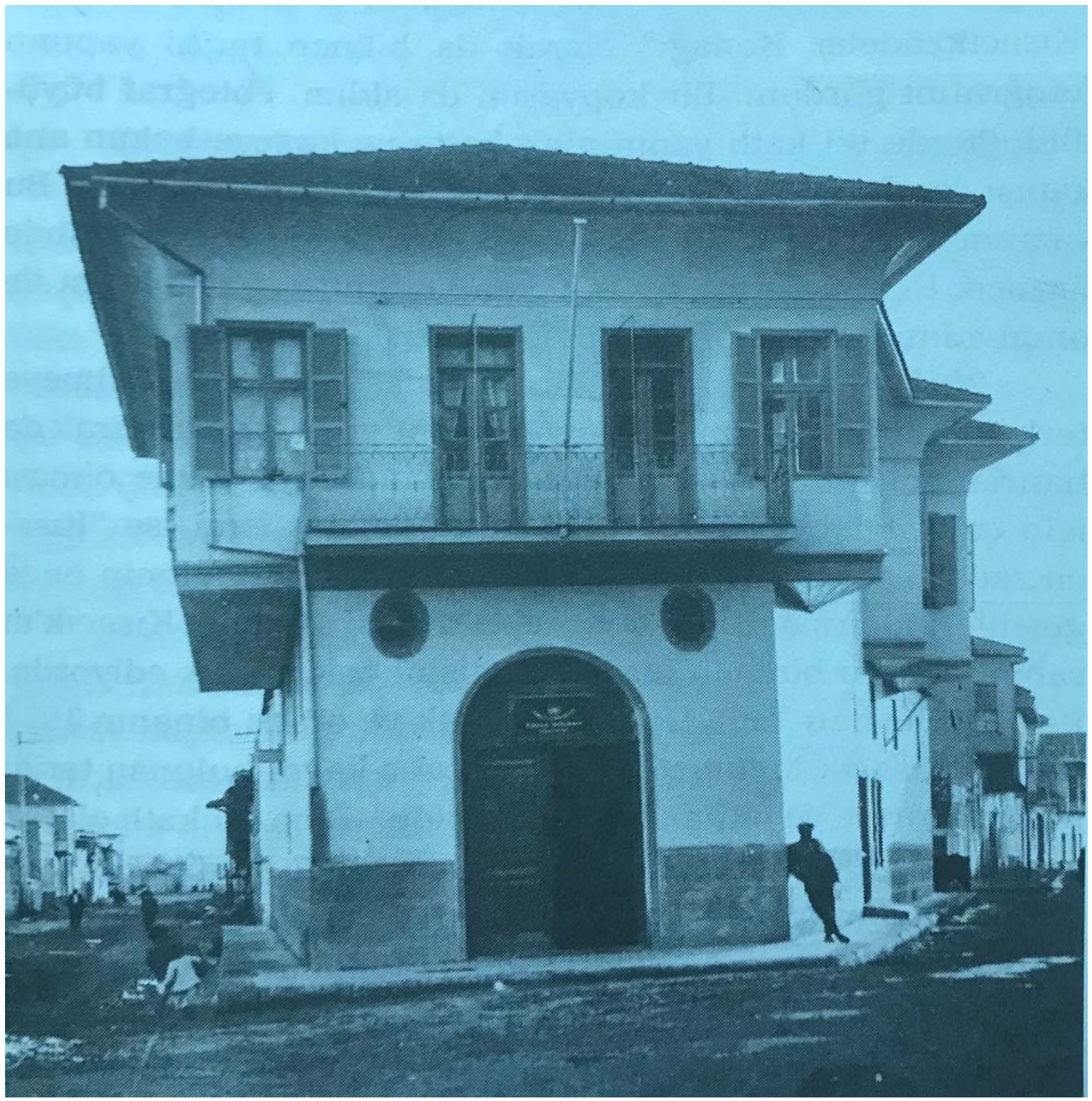

Foto 1. Adana Düyun-u Umumiye ve Reji İdaresi olarak kullanılan yap1 (Yurtsever, 2017, s. 151).

İdare daha sonra ise 1882 yılında Eski Köprü ile Yeni Köprü arasında yaptırılan "Suphi Paşa Konağl" olarak nitelendirilen yapıyı ikametgâh olarak kullanmıştır. Bu bina 1902 yılında Adanalı Suphi Paşa tarafından satın alınarak yapıya yeni eklemeler yapılmıştır (Kaş, 2012, s. 8).

İdare, elde edilen gelirleri arttırmak amacıyla 1884 yılında tütün üretiminin yoğun olarak yapıldığı Samsun, Trabzon, İstanbul ve İzmir gibi bölgelerde tütün işletme fabrikaları kurmaya başlamıştır (Pamuk, 1984, s. 50). Bir diğer ifadeyle tütünü işleyerek sigara imal eden fabrikaları kuran (Demir, 2019, s. 424, 437; Dığıroğlu, 2014, s. 234) Reji İdaresi, 1895 yılında Adana vilayetinde de tütünün işlenip sigara olarak piyasaya sürülmesi amacıyla fabrika inşa etmiştir (Öztürk ve Keskin, 2013, s. 98; Eldem, 1994, s. 77). Adana vilayetinde yıllık ortalama 150 ile 200 ton tütün üretimi yapıldığ1 tespit edilmiştir. Tütün üretiminin yoğun olarak yapıldığ1 vilayette kurulan tütün fabrikasında çoğunlukla kadın ve çocuklar çalışmıştır. Fabrika için uzun süre kiralanan binalar depo ve imalat alanı olarak kullanılmıştır (Konur Çakmak, 2019, s. 119).

İdarenin Adana vilayetindeki teşkilat yapısına bakıldığında ise merkez şubesi Adana merkez sancağında kurulmuştur. Merkez şubeye bağlı olarak İçel Sancağı, Cebel-i Bereket Sancağı, Kozan Sancağı ve Mersin

\footnotetext{
${ }^{5} 1891$ yılına ait vilayet salnamesinde, köprünün şehir tarafında bulunan girişinde bir otel yaptırıldığ 1 ve bu otelin belirli bir süreliğine kiralanarak Reji Nezareti tarafından kullanıldığı bilgisi aktarılmıştır. Bu otel, Şerafettin Mağmumi'nin eserinde “Deli Mehmet'in Oteli” olarak geçmektedir (Telci, 2000, s. 317; Hasgül, 2016, s. 220).
} 
Sancaklarında birer müdürlük oluşturulmuştur. Müdürlüklere bağlı olan Mut, Ayaş, Payas, Hamidiye, İslahiye, Karataş, Yumurtalık, Bahçe, Feke, Haçin, Karaisalı, Ermenek, Anamur, Gülnar, Bulanık ve Tarsus gibi kaza ve nahiyelere ise memurlar atayarak vilayet genelinde tütünün üretimini, ticaretini ve tüketimini denetim altına almaya çalışmıştır. (Adana Vilayet Salnamesi, Hicri 1308, s. 66, 127, 120; Adana Vilayet Salnamesi, Hicri 1309, s. 141-143, 184). İdare'nin Adana'ya bağlı olan Kadirli'de de örgütlemesini sağladığ bilgisine Reji Dairesi'nin başında bulunan Patraki ismindeki bir şahsın görev yapmasından anlaşılmaktadır (Yurtsever, 1981, s. 164). Adana Reji İdaresi’nin, 1892 tarihli vilayet salnamesine göre Sis ${ }^{6}$ kazasında da aktif olduğu tespit edilmiştir (Aydın, 2019, s. 46-48).

1883 yılında kurulan Reji İdaresi’nin imparatorluk genelinde uğraştığı en büyük sorunlardan biri kaçakçılık faaliyetleri olmuştur. İmparatorluk genelinde olduğu gibi Adana vilayetinde de 1883 yılından itibaren tütünün Reji İdaresi'nin denetimi altına girmesiyle birlikte mücadele ettikleri önemli sorunlardan biri kayıt dışı ekonomi faaliyetleri olmuştur. Bölgede meydana gelen kaçakçılık faaliyetlerinde artışın yaşanmasına neden olan gelişmelerin başında ise üreticinin elinde bulunan ürünün idare tarafindan düşük fiyata alınması ve tüketiciye yüksek fiyata satılmasının hem üreticiyi hem de tüketiciyi kaçakçılığa yöneltmiş olması gelmektedir. $\mathrm{Bu}$ sebepler dışında bölgede idare tarafından yeterli ambarın yapılmaması, ambarlarda tutulan tütünlerin idareciler tarafından çürümeye terk edilmesi, tütünün düşük fiyata satın alınması gibi gerekçelerden dolayı ambar sorunun yaşanması, idareciler tarafından ekim için verilen ruhsatlarda zorluk çıkarılması gibi gerekçelerden dolayı ekim ruhsatnamesi sorunun yaşanması ve yüksek vergilendirme ile pul yapıştırma meseleleri üretici, tüketici ve tüccarı kaçakçılığa yönelten diğer sebepler arasında yer almıştır. Diğer bir etken olarak ise toplum içerisinde bazı kesimlerin kaçakçılığı geçim kapısı olarak görmesi gösterilebilir (Kazgan, 2017, s. 29). Bölgede özellikle kaçakçılığı geçim kapısı olarak gören Hemavendlilerin de kaçakçılık faaliyetlerine karıştı̆̆ına dair iddialar olmuştur. (BOA, DH. MKT, 1779/111, 10 Kasım 1890; BOA, DH. MKT, 1772/ 124, 18 Ekim 1890).

Çalışmanın amaç ve yöntemi; Reji İdaresi, Osmanlı İmparatorluğu’nun sosyal, iktisadi ve ekonomik hayatında önemli bir role sahip olmuştur. İdarenin sosyal ve ekonomik hayattaki öneminin yanı sıra asayiş açısından da konumu yadsınamayacak kadar önemlidir. Ancak İdareyle ilgili yapılan çalışmalarda idarenin teşkilat yapısının yanı sıra işleyişi ve ekonomik yapısına odaklanılmasından dolayı, idarenin vilayetlerdeki kayıt dışı ekonomi $^{7}$ ve asayiş alanındaki önemi göz ardı edilmiştir. Bu bağlamda araştırmamızın amacı 1883 yılında Reji İdaresi'ne bağlı olan Adana Reji İdaresi'nde meydana gelen kayıt dışı ekonomi ve asayiş bağlamında Hemavend Aşireti ile ilgili olan tütün kaçakçılığı iddialarıdır. Çalışma sürecinde bilhassa, Kaçakçılık faaliyetleri karşısında Adana Reji İdaresi yöneticileri ile yerel idarecilerin tutumlarının neler olduğu? Hemavend Aşireti'ne mensup olan vatandaşların bu iddialar karşısındaki tutumunun ne olduğu? Devlet makamlarının bu iddiaların gerçekliğini araştırma sürecini nasıl işlettikleri? Sorularına cevap aranmaya çalışılmıştır.

Araştırmanın konu ve kapsamı; Adana, Osmanlı İmparatorluğu'nda müstakil bir vilayet olarak Adana, Kozan, Cebel-i Bereket, Mersin ve İçel sancakları şeklinde idari bölgelere ayrılmıştır. Merkez sancak ile birlikte 5 sancaktan oluşan Adana vilayetindeki tütün alanında meydana gelen kayıt dışı ekonomi girişimleri ve beraberinde bölgede oluşan asayiş sorunlarını tümüyle ele almak mümkün olmadığından delayłaraştırmamızın sınırlarını Hemavend Aşireti'nin bölgedeki faaliyetleri ile sınırlandırdık. Ayrıca Reji İdaresi’nin Adana vilayetindeki faaliyetlerini tüm yönleriyle incelemek bir makalenin sınırlarını aşan durum olduğundan vilayetteki aşiret üyelerinin yerleşim süreci, aşiret üyelerinin devlet kurumlarına yerleştirilmesi, idarenin teşkilatlanma süreci ile aşiretin tütün alanındaki kayıt dışı ekonomi girişimlerine dair iddiaları ele almakla yetindik. Çalışmada karşılaşılan önemli problemlerden biri literatürde bu alanda yeterli çalışmanın bulunmamış olmasidir.

Araştırma neticesinde elde edilen bulgulara göre daha önce ikamet etmiş oldukları bölgelerde geçimlerini kaçakçılıkla sağlayan aşiret mensupları, bölgede yerleşik hayata geçtikten sonra bu alışkanlıklarını terk etmek ve devlete bağlılıklarını sağlamak amacıyla devlet kurumlarında görevlendirilmişlerdir. Kaçakçılık iddialarının aslının olup olmadığını öğrenmek maksadıyla yapılan tahkikat neticesinde idarecilerin aşiret mensupları hakkında zihinlerinde oluşan ön yargı kırılmıştır. Aşirete mensup olup okuma yazma bilen kişilerin devlet kurumlarına yerleştirilmesinin ise yasadışı işlerin önünün alınmasında etkin rol oynadığı tespit edilmiştir.

Materyal ve Metot, Hemaven Aşireti ile ilgili ortaya atılmış kaçakçılık iddialarıyla ilgili arşivler, resmi yayımlar, salnameler ve araştırma eserlerin taraması yapılmıştır. Tarama neticesinde elde edilen veriler

\footnotetext{
${ }^{6}$ Kozan sancağının eski çağlarda kullanılan ismidir (Kurt ve Ünlü, 2014: xı).

${ }^{7}$ Kayıt dışı ekonomi genel anlamda devletin bilgisi ve kontrolü dışındaki kanuni ve kanun dışı faaliyetlerin tümü için kullanılan tabirdir (Erkuş ve Karagöz, 2009: 127).
} 
toplanmış ve teorik çerçeve çizilmiştir. Aşiret mensuplarının Adana vilayetine yerleştirilmeleriyle ilgili süreç incelenerek ortaya atılmış olan kaçakçılık iddiaları kaynaklar ışı̆̆ında analiz edilmiştir.

\section{Hemavend Așiret Mensuplarının Adana Vilayetine Yerleștirilme Süreci}

Süleymaniye'ye bağlı olan Surtaş Nahiyesinde ${ }^{8}$ müdürlük görevini yapmakta olan ve ailenin önde gelen simalarından biri olan Kake Abdullah Bey ile birlikte beraberindeki akrabaları farklı tarihlerde Adana bölgesine göç etmişlerdir. Gerçekleşmiş olan bu göçlerden biri de II. Abdülhamit döneminde meydana gelmiştir. Süleymaniye bölgesinden Anadolu'ya göç eden ilk kafile 223 haneden oluşmuştur. Gelen bu kafileden İsmail Hakkı Paşa'nın tavsiyesi üzerine 100 hanesinin Sivas'a, 23 hanesinin Konya'ya, 50 hanesinin Adana'ya ve yine 50 hanesinin ise Ankara'ya yerleştirilmesi yönünde karar alınmıştır (BOA, DH. MKT, 1446/29, 12 Eylül 1887; BOA, İ. MMS, 92/3888/4, 4 Ağustos 1887; Demir, 1993, s. 199-201). Bu karar Musul vilayetinde eşkıyalık faaliyetlerinde bulunan Hemavendlilerin cezalandırılması ve bölgede çoğunluğu oluşturup bu gibi faaliyetlere girişmemeleri amacıyla alınmıştır (Demirci ve Çabuk, 2015, s. 42). Adana'ya yerleștirilen 50 hanelik Hemavendlilerden sonra 23 Kasım 1889 tarihinde aynı aşirete mensup olan Kake (Kage) Abdullah Bey ile birlikte 63 kişinin Bingazi’ye sürgün olarak gönderilmesine karar verilmiştir. Kafile Bingazi'ye gönderilmek maksadıyla İzmir'de bulunduğu sırada Abdullah Bey'in affının talep edilmesi ve devlet yöneticilerinin de uygun bulması neticesinde o ve beraberindekilerin Bingazi'ye değil de Adana'ya yerleştirilmesine karar verilmiştir (BOA, MV, 34/59, 8 Ağustos 1888). Kake Abdullah Bey'in akrabalarıyla birlikte Adana'ya yerleştirilmesinden sonra daha önce Bingazi'ye gönderilmiş olan diğer aile fertlerinin de 1893 yılında Adana'ya yerleştirilmesi talebi olumlu karşılanmıştır (BOA, DH. MKT, 35/46, 11 Mayıs 1893). Yine Kake Abdullah'ın yapmış olduğu talep üzerine gelen bu nüfusa ek olarak Bingazi'de bulunan 90 nüfuslu Hemavendlilerin Adana'ya yerleştirilmesine izin verilmişstir (BOA, DH. MKT, 1936/46, 25 Mart 1892). Adana vilayetine yerleştirilmiş olan nüfusun geçimlerini sağlayabilmeleri amacıyla uygun bir işte istihdam edilmeleri veya ziraat yapabilmeleri için arazi dağıtılması kararlaştırılmıştır. Ancak bu işlemler yapılana kadar geçecek zaman zarfında geçimlerini sağlayabilmeleri için nüfus başına 60 'ar kuruş yevmiye verilmesinin yanı sıra yetişkin Hemavendlilere 300, küçüklerine ise 200 dirhem ekmek parası verilmesi kararlaştırılmıştır (BOA, MV, 34/59, 8 Ağustos 1888).

Farklı tarihlerde Adana'ya yerleştirilmiş olan aşiret mensuplarının artan göçleri bölgedeki nüfuslarının gittikçe artmasına yol açmıştır. Artan nüfus beraberinde kontrolsüzlügü ve asayiş sorunlarını da getirmiştir. Yine fazla nüfusunun beraberinde getirmiş olduğu bir diğer sorun da ekonomik anlamda olmuştur. Vilayette yaşayan Hemavendliler parasal anlamda idarecilere ağır yük olmaya başlamışlardır. Bu gibi nedenlerden dolayı bölge yöneticileri bu aşirete mensup kişilerin bir arada yaşamalarını engellemek ve bölgede nüfus çoğunluğunu sağlamalarının önünü almak amacıyla çözüm aramaya başlamışlardır (BOA, DH. MKT, 380/15, 30 Mayıs 1895). Bu gibi çözüm arayışı içerisinde olan yöneticilerden biri de Adana Valisi Mustafa Faik Paşa olmuştur. Vali Paşa Hemavendlilerin bölgeye olan göçünü durdurmak için bir takım girişimlerde bulunmuş olsa da bunda pek başarılı olamamıştır (Aycan, 2017, s. 76-78). Nitekim 25 Kasım 1888 tarihinde Adana'da bulunan Hemavendlilerin barınma ihtiyaçlarının imkânsız hale gelmiş olması, nüfuslarının artmasına bağlı olarak kontrol altında tutulmalarının zorlaşmış olması ve asayiş sorunlarına neden olmalarından dolayı Bingazi ve Trablusgarp'a tekrar geri gönderilmeleri girişimlerinde bulunulmuştur. Ancak Adana valiliğinin bu girişimleri Kake Abdullah Bey'in ailesi ve gelen grupların son altı yıl içerisinde herhangi bir yasadışı işe karışmamaları gerekçe gösterilerek Dâhiliye Nezareti tarafindan karşılık bulmamıştır (BOA, DH. MKT, 1568/36, 25 Kasım 1888; BOA, DH. MKT, 1570/7, 1 Aralık 1888). Adana valiliğinin talebinin reddedilmesiyle birlikte Adana'ya yerleştirilmiş olan nüfusun uygun memurluklara yerleştirilmesi ve işleyebilecekleri arazinin kendilerine dağıtılmasına kadar geçecek zaman zarfinda geçimlerini sağlamak amacıyla daha önce bağlanan yevmiyelerin verilmesine devam edileceği yönünde alınan karar vilayete iletilmiştir (BOA, DH. MKT, 1547/13, 25 Eylül 1888).

Vilayete iletilen kararda Adana'da bulunan Hemavendlilerin büyüklerine 3'er, küçüklerine ise 2'şer kuruştan toplamda aylık 157 kuruş verilmesi gerektiği belirtilmiştir. Bireylerin barınmaları için tutulan hanelerin kirası olan 200'er kuruşluk ödemelerin de yapılmasına devam edilmesi yönündeki karar vilayete bildirilmiştir (BOA, DH. MKT, 1623/18, 14 Mayıs 1888; BOA, DH. MKT, 1617/128, 20 Nisan 1889). Kake Abdullah Bey ile birlikte Adana vilayetine yerleştirilmiş olan 68 nüfuslu haneden 22'sinin daha önce hiç tarımla uğraşmadıkları tespit edilmiştir. Tarım ile ilgili olmayan bu kesimin araziyi idare edemeyecekleri göz önünde bulundurularak kendilerine arazi verilmemesi yönünde karar alınmıştır. Ancak aylık masraflarının karşılanması amacıyla 2500 kuruşun kendilerine tahsis edilmesi kararlaştırılmıştır (BOA, DH. MKT, 1973/16, 18 Temmuz 1892). Geri

\footnotetext{
${ }^{8}$ Sözlük anlamı olarak taraf, cihet yöre, kenar, bölge anlamına gelen nahiye Osmanlı idari sisteminde Tanzimat'tan sonra kazadan küçük idari birimler için kullanılmıştır (Şahin, 2006, s. 306-307).
} 
kalan 46 nüfusluk hane ile Trablusgarp'tan gelecek olan 93 nüfusluk ${ }^{9}$ haneler içerisinde ziraat yapabilecek durumda olan aşiret mensuplarına 2.740 dönümlük arazi dağıtılması kararlaştırılmıştır. Arazi verilen ailelerin toprağı işleyebilmeleri amacıyla gerekli olan öküz ve tarım aletlerinin elde edilmesi amacıyla 27.400 kuruşun yanı sıra her türlü ihtiyaçlarının giderilmesi için toplamda 84.209 kuruş para verilmesi yönünde karar alınmıştır (BOA, DH. MKT, 1904/2, 22 Aralık 1891; BOA, DH. MKT, 1884/15, 31 Ekim 1891).

\section{Kake Abdullah Bey ve Beraberindekilerin Memurluğa Yerleştirilme Sureci}

Süleymaniye'den ${ }^{10}$ Adana'ya eşi ve çocukları ile birlikte gelen Kake Abdullah Bey'in daha önce Süleymaniye'ye bağlı olan Surtaş ${ }^{11}$ nahiyesinde müdürlük görevinde bulunduğu yukarıda belirtilmişti. Daha önce nahiye müdürlüğü görevi icra etmiş olması göz önünde bulundurularak merkez hükümet tarafından müsait bir işe yerleştirilmesi Adana valiliğinden 2 Aralık 1887 tarihinde talep edilmiştir (BOA, DH. MKT, 1474/16, 3 Ocak 1888). Kake Abdullah Bey'in son altı yıl içerisinde gerek Adana'da gerekse başka bölgelerde herhangi bir yasadışı işe bulaşmamış olması göz önünde bulundurularak talep değerlendirmeye alınmıştır. Hem himayesinde bulunan nüfusun kayıt dışı ekonomi faaliyetlerine girişmesinin önünü alarak devlete olan bağlılıklarını arttırmak hem de Adana vilayetinde yaşayan aile fertleriyle birlikte perişan durumlarının iyileştirilmesi maksadıyla Abdullah Bey'in uygun bir memurlukta istihdamı için girişimlerde bulunulmuştur (BOA, DH. MKT, 1474/16, 3 Ocak 1888). Merkez hükümetin Kake Abdullah Bey'in uygun bir nahiye müdürlüğü görevinde istihdam edilmesi yönündeki telgrafına karşılık, Adana valiliği, Abdullah Bey’in Türkçesinin iyi olmaması nedeniyle nahiye müdürlüğüne atamasının yapılamayacağı cevabını vermiştir. Ancak kendisi ve beraberinde gelmiş olan kişilerin geçimini sağlamak amacıyla kişi başına 60'ar kuruş yevmiye verilmesi kararı tekrarlanarak Kake Abdullah Bey'in müdürlüğe tayini gerçekleşse bile buradan alacağı maaşla 59 kişilik bu ailenin geçimine yetmeyeceğine dikkat çekilmiştir. Dâhiliye Nezareti, bu kişilerin geçimlerini sağlamak için koşulların olgunlaşmasına kadar geçecek zaman zarfında yetişkin Hemavendlilere 300, küçüklerine ise 200'er dirhem ekmek parası verilmesi yönündeki kararı onaylamıştır (BOA, DH. MKT, 1528/112, 4 Ağustos 1888).

Kake Abdullah Bey beraberindeki aile fertleriyle birlikte 1894 yılında Hamidiye Süvari Alaylarına katılma talebinde bulunmuştur. Ancak bu talep hükümet tarafından olumlu karşılanmamıştır (BOA, MV, 74/49, 15 Mayıs 1893; BOA, BEO, 1239/92902, 10 Aralık 1898; BOA, BEO, 1165/87359, 27 Temmuz 1898). Kake Abdullah Bey'in Türkçe okuryazarlığının olmaması herhangi bir kaymakamlıkta veya tabur ağalığına tayininin yapılmasında en büyük engel olarak tespit edilmiştir. Herhangi bir işe istihdam edilmemiş olmasından dolayı kendisine bağlanan 3 kuruşluk aylığın 10 kuruşa çıkarılması yönünde karar alınmıştır (BOA, DH. MKT, 1796/29, 29 Aralık 1890; BOA, DH. MKT, 2428/103, 16 Kasım 1900). Ancak daha sonraları yapılmış olan araştırmalar neticesinde merkez hükümet ile Adana valiliği arasında meydana gelen yazışmalar sonucunda Abdullah Bey'in ikamet etmekte olduğu Adana'da tabur ağalığına istihdamının yapılması yönünde herhangi bir engel olmadığı anlaşılmıştır. Atamanın bir an önce gerçekleştirilmesi amacıyla gerekli işlemlere başlanması için Adana vilayetine telgraf çekilmiştir (BOA, DH. MKT, 1700/5, 17 Şubat 1890; BOA, DH. MKT, 1825/80, 5 Nisan 1891).

Kake Abdullah Bey ve Mehmet Bey ile birlikte gelmiş olan akrabaları arasında şartları sağlayan ailenin önde gelenlerinin bir işte istihdam edilmeleri yönünde alınan kararın nedenleri arasında daha önce de belirtildiği gibi bu grupların yasadışı işlere girişmelerini engellemek, devlete olan bağlılıklarını arttırmak ve geçimlerini sağlayabilmektir. Bu doğrultuda iyi halleri göz önünde bulundurularak kafilenin önde gelenlerinin bir tabur ağalığına yerleştirilmesi kararlaştırılmıştır. Himayeleri altında bulunan kişilerin ise zaptiye veya Reji İdaresi’nde istihdam edilmeleri yönünde karar alınmıştır. Bu gibi kurumlara yerleştirilmeleri sayesinde hem almış oldukları yevmiye ile ailelerin ihtiyaçlarını giderecekler hem de tabur ağalığı gibi inzibati görevde bulunarak bölgedeki asayişin sağlanmasına katkıda bulunacaklardı. Yine bu gibi görevlerde bulunmaları bölgedeki kaçakçılık faaliyetlerinin de önünün alınmasında büyük katkı sağlayacağı öngörülmüştür (BOA, DH. MKT, 2407/8, 25 Mart 1887). Yapılan bu talep üzerine Abdullah Bey ile Mehmet Bey’in Cebel-i Bereket ile İçel Sancaklarına tabur ağası olarak atamasının yapıldığı tespit edilmiştir. Kake Abdullah Bey ve

\footnotetext{
91891 yılında Trablusgarp'tan Adana'ya gelen bu nüfusun bölgeden kaçmasının önünün alınması amacıyla bir an önce Adana'da kendilerine arazi tahsis edilmesi talebinde bulunulmuştur (BOA, DH. MKT, 1878/85, 15 Ekim 1891; BOA, DH. MKT, 1894/15, 26 Kasım 1891; BOA, DH. MKT, 1936/46, 25 Mart 1892; BOA, DH. MKT, 35/46. 11 May1s 1893).

${ }^{10}$ Hemavendlilerin 1855 yılında daha çok Süleymaniye'nin Bağdat kazasında yaşadıkları tespit edilmiştir (Sezen, 2006, s. 41).

${ }^{11}$ Süleymaniye vilayetine bağlı olan Surtaş nahiyesi vilayetin kuzeyinde yer almaktadır (Gündüz, 2010, s. 111-113).
} 
beraberindekilerin çoğu her ne kadar eşkıyalık ${ }^{12}$ ve kaçakçılık gibi faaliyetlere girişmemiş olsalar da gelen bu nüfustan 15 kişilik grubun firar ederek eşkıyalık ve kaçakçılık gibi yasadışı işlere bulaştıkları tespit edilmiştir. Daha önce ikamet etmiş oldukları bölgelerde de geçimlerini kayıt dışı ekonomiden sağlamaları göz önünde bulundurulduğunda bu kesime şüphe ile bakılmıştır. Nitekim Adana bölgesine yerleştirilmiş olan Hemavendlilerle ilgili birçok kaçakçılık iddiası ortaya atılmıştır (BOA, DH. MKT, 2120/28, 19 Ekim 1898; BOA, DH. MKT, 2152/30, 24 Aralık 1898).

\section{Hemavendlilerin Adana'da Tütün Kaçakçılığı Yaptıklarına Dair İddialar}

Hemavend Aşireti'ne mensup olan nüfusun imparatorluk genelinde olduğu gibi Adana vilayetinde de zamanla artış göstermesi beraberinde bölgede çeşitli sorunların doğmasına neden olmuştur. Yaşanan bu sorunlardan biri de bölgede asayiş sorunlarına neden olan kayıt dışı ekonomi olarak nitelendirebileceğimiz kaçakçılık faaliyetleri olmuştur. Bu faaliyetler arasında bilhassa Reji İdaresi'nin denetiminde olan tütün alanında meydana gelen kayıt dışı ekonomi girişimlerine yönelik iddiaların olduğu tespit edilmiştir. Daha önce ikamet etmiş oldukları bölgelerde bu gibi faaliyetler ile geçimlerini sağlamaya çalışan Hemavendliler Kerkük ve Süleymaniye bölgesinden Adana vilayetine göç etmişlerdir. Göç eden bu gruplar içerisinde 15 veya 20 kişilik bir kafilenin 1889 yılında Adana'da alınan her türlü önlem ve tedbire rağmen firar ederek başta eşkıyalık olmak üzere kaçakçılık gibi bir takım yasadışı faaliyetlerde bulundukları tespit edilmiştir (BOA, Y. PRK. KOM, 6/25, 10 Ocak 1888). Nitekim bu grupların Adana'ya gelmeden önce ikamet etmiş oldukları Musul, Süleymaniye ve Bağdat gibi vilayetlerde de tütün kaçakçılığı ve eşkıyalık gibi kayıt dışı ekonomi faaliyetlerinde bulunarak elde ettikleri ganimetlerle geçimlerini sağlamaya çalıştıkları tespit edilmiş̧ir (BOA, DH. MKT, 1779/111, 10 Kasım 1890; BOA, DH. MKT, 1772/124, 18 Ekim 1890; Hanilçe, 2018: 226).

Adana vilayetine yerleştirilmiş olan Hemavendlilerin bölgede kaçakçıllk faaliyetinde bulunduklarına dair ilk iddia 27 Eylül 1899 tarihinde ortaya atılmıştır. Arşiv belgelerinden elde edilen bulgulardan yola çıkılarak aşirete mensup 150 veya 200 kişilik bir grubun martini tüfeği ${ }^{13}$ ile silahlanmış olarak Adana ve çevresinde eşkıyalık vesaire yasadışı işlere bulaştıkları tespit edilmiştir. Silahlı olan bu kafilelerin eşkıyalık dışında bölgede önemli bir gelir kalemi durumunda olan tütün alanında da kaçakçılık yapmakta olduklarına dair bilgiler de tespit edilmiştir. Aşiret mensuplarının bölgedeki bu gibi faaliyetler içerisinde bulunmaları Adana Reji İdaresi'nin tepkisine neden olmuştur. Bu tepkinin altında yatan temel sebep bu gibi kayıt dışı ekonomi faaliyetlerinin idarenin bölgede elde etmiş olduğu aylık gelirlerinde ciddi düşüşlerin yaşanmasına neden olmasından kaynaklanmıştır. Gelirlerin düşmesine neden olan bu gibi yasadışı faaliyetlerin hem idarenin hem de devletin çıkarlarına zarar vermesinden dolayı şartnamede belirtildiği gibi bu gibi kayıt dışı ekonomi faaliyetlerinin önlenmesi amacıyla imparatorluk genelinde olduğu gibi Adana Reji İdaresi de yerel idareciler ile işbirliği yoluna gitmiştir. Yerel yöneticiler ile reji yöneticileri arasında yürütülen görüssmeler neticesinde bu gibi faaliyetlerin engellenmesi ve meydana gelen gelir kaybını engellemek amacıyla gerekli önlemlerin alınması konusunda fikir birliğine varılmıştır. Bu doğrultuda kaçakçılıkla mücadelede etkin rol oynayan Reji Nezareti'nin kolluk kuvvetleri olarak nitelendirilebilecek kolcular $^{14}$ tayin edilmiştir. Yapılan araştırmalar neticesinde 150 veya 200 kişilik kaçakçı grubunun içerisinde tütün alanında meydana gelen faaliyetlerde görevi başında olan kolcuların da etkisinin olduğu tespit edilmiştir. Tespitin gerçekleşmesiyle birlikte idarede bulunan görevlilerin uyarılması ve gerekli önlemlerin alınması amacıyla reislerine 27 Eylül 1899 tarihinde tembihatta bulunulmuştur. Aslında Hemavendlilerin bu gibi görevlere getirilmesindeki önemli etkenler arasında, geçimlerini sağlamak amacıyla verilen maaşlardan dolayı devlete külfet yaratmaları ve gerek bölgedeki asayişsizliğin önlenmesi gerekse bu mali külfetten kurtulmak olarak gösterilebilir. Ancak bölgede bu gibi kaçakçlık faaliyetlerine her ne olursa olsun hiçbir şekilde izin verilmemesi ve önlenmesi amacıyla gerekli görülen tüm önlem ve tedbirlerin alınmasıyla suçluların yakalanarak cezalandırılması yönünde karar Adana vilayetine bildirilmiştir (BOA, DH. MKT, 2269/91, 13 Kasım 1899).

Adana valiliğinden merkez hükümete çekilen telgrafta bölgede 150 veya 200 kişilik Hemavendlinin eşkıyalık ve tütün kaçakçılığı yaptıkları ile ilgili iddiaların araştırılması talep edilmiş̧ir. Merkez hükümet tarafindan görevlendirilen memurlar aracıllğı ile yapılan tahkikat neticesinde zikredilen bu kaçakçı kafilenin daha önce Adana'ya yerleştirilmiş olan eski Surtaş nahiye müdürü Kake Abdullah ve arkadaşı Mehmet Bey ile bağlantılarının olmadığı tespit ederek Adana vilayeti’ne bildirmiştir. Yine yürütülen tahkikat neticesinde Kake

\footnotetext{
12 Eşkıyalık faaliyetleriyle nam salmış olan Hemavendlilerin 1885 yılında Musul Vilayetine tabi oldukları yıllarda firar ederek İran Devleti'ne sığınmaları ve oradan Osmanlı sınırlarına saldırmaları üzerine Osmanlı ile İran Devleti arasında sorunun yaşanmasına neden olmuşlardır (BOA, Y. A. HUS, 184/106, 29 Ekim 1885).

13 İngiltere'de üretilen Martini Henry tüfeklerinden 1872 y1lında Osmanlı İmparatorluğu tarafindan 200 bin adet iğneli tüfek olarak nitelendirilen 1871 modeli satın alınmıştır (Soyluer, 2018, s. 297).

14 Devlet gelirlerinin kaybının ve kaçakçılık faaliyetlerinin önlenmesi amacıyla görev yapan bekçi veya memurlar için kullanılan tabirdir (Karamursal, 1989, s. 136; Yurtsever, 2010, s. 226-227).
} 
Abdullah Bey'in Adana bölgesinde himayesi altında 50 veya 60 kadar akrabasının bulunduğunu, bunların da çoğunun çocuk ve kadınlardan oluştuğu tespit etmiştir. (BOA, DH. MKT, 2292/89, 2 Ocak 1900). Nitekim Kerkük, Bağdat, Musul ve Süleymaniye bölgelerinden Anadolu topraklarına göç eden Hemavendlilerin çoğunluğunun kadınlardan oluştuğunun bilinmesi bu tezi destekler nitelikte olmuştur (Alan, 2014, s. 248). Yine hükümet tarafindan Adana valiliğine yazılan cevapta Kake Abdullah Bey’in himayesinde yaşamakta olan nüfusun ehli namus oldukları ve bu gibi yasadışı işlere karışacak durumda olmadıkları ifade edilmiştir. Martini tüfeği ile silahlanarak bölgede tütün kaçakçılığı ve eşkıyalık faaliyetlerinde bulunan 150 veya 200 kişilik asi grubun ise söz dinlemeyen itaatkâr olmayan Çeçen ve Çerkes gruplarından oluştuğu ifade edilmiştir. Bu suçluların yakalanarak cezalandırılması için ise valilikten gerekli önlem ve tedbirlerin alınması istenmiştir. Ancak bölgede alınan tüm bu önlemlere rağmen bu gibi kaçakçılık faaliyetlerinin önünün alınamadığı tespit edilmiştir. 27 Ağustos 1899 tarihinde Adana Reji İdaresi tarafindan tutulmuş olan kayıt defterleri incelendiğinde kayıt dışı ekonomi girişimlerinin bölgede yaygın olarak meydana geldiği tespit edilmiştir. Bu tarihlerde tutulan kayıtlarda yapılan inceleme neticesinde Reji İdaresi'nin denetimi altında bulunan tütün gelirlerinin azalmasına neden olan sebepler arasında kayıt dışı ekonomi faaliyetlerinin \% 80 oranında olduğu tespit edilmiştir (BOA, DH. MKT, 2292/89, 2 Ocak 1900).

Hemavend Aşireti'ne mensup olup Adana bölgesinde ikamet etmekte olan Osmanlı tebaasının kaçakçılık faaliyetlerinde bulunduklarına dair bir diğer iddia örneği ise Nikde adında bir tüccar ile ilgili olmuştur. Kaçakçılık fiiliyatının, Nikde adındaki Sömbekili olan süngerci ile Tarsus bölgesinde ikamet etmekte olan Giritli Mustafa Befaki tarafından gerçekleştirildiği tespit edilmiştir. İddianın ortaya atılması üzerine Adana valiliği tarafından bölgede yapılan araştırma neticesinde Adana vilayetine bağlı Karataş kazasına deniz yolu ile Arsuz ${ }^{15}$ bölgesinden getirilen dinamit ve tüfek gibi patlayıcı maddelerin yanı sıra kaçak tütün getirilmeye çalışıldığ 1 tespit edilmiştir. Karataş bölgesinden Arsuz'a kaçak şekilde hareket eden bir kayıkta kaçak dinamit, silah ve tütün olduğunun tespit edilmesi üzerine yapılan takibat neticesinde Sömbekili Süngerci Nikde ile Giritli Mustafa Befaki adındaki kayıkçılar kaçak mallarla birlikte derdest edilmiştir. Kayığın kıyıya çekilmesiyle birlikte kayıkta yapılan arama neticesinde 71 torba içerisinde 821 kıyye $^{16}$ (yaklaşık 1 ton) dinamit, 50 tüfek ve bunların yanı sıra farklı markalara ait silahlar bulunmuştur. Kaçak olarak bölgeye sokulmaya çalışılan bu maddelerin Adana'da bulunup eşkıyalık ve kaçakçılık girişimlerinde bulunan Hemavend Aşireti'nin mensuplarına verileceği anlaşılmıştır. Adana valiliği ile İskenderun Kaymakamlığı arasında yapılan yazışmalar neticesinde 31 Temmuz 1903 tarihinde bu kişilerin yasaklanmış olan bu gibi ürünleri satmak amacıyla Adana'da bulunan Numan Usta adındaki şahıs ile irtibat kurdukları tespit edilmiştir. Yine yakalanan kayıkçıların sorgulaması ve üstlerinin aranması neticesinde üzerlerinden çıkan eşyalar arasında telgraf ve mektuplar da bulunmuştur. Bulunan bu mektup ve telgraflar arasında Numan Usta adındaki şahıs ile bağlantı kurulduğuna ve haberleşildiğine dair telgraflar tespit edilmiştir. Rumca kaleme alınan mektupların tercüme işlemlerinin yapılması amacıyla el konulmuştur. Yazışmaların Rumca yapılmış olması kaçakçılık girişiminde bulunanların Rum asıllı oldukları hakkında bize ipuçları vermektedir. Bölgede meydana gelen ve bölgenin asayiş düzeninin bozulmasına neden olacak bu gibi kayıt dışı ekonomi girişimlerinin engellenmesi amacıyla Adana vilayetinin sahil kıyılarında tedbirlerin arttırılmasına dikkat çekilmiştir Beyrut vilayetinin de aynı hassasiyeti göstererek gerekli önlemlerin alınması yönünde ikaz edildiği tespit edilmiştir. (BOA, DH. ŞFR, 311/7, 27 Eylül 1901).

Sömbekili Süngerci Nikde ile Giritli Mustafa Befaki’nin denetiminde bulunan bir kayık içerisinde bulunan kaçak malların detayına bakıldığında ise bir miktar kaçak tütün, üzerlerinde Türkçe ve Rumca yazılı yirmi beş adetten oluşan mektuplar, 71 torba içerisinde 821 kıyye dinamit ile 50 tüfek olduğu tespit edilmiştir. Bu kaçak mallar İskenderun'a çıkarılmaya çalışılmıştır. Ancak kolluk kuvvetlerinin olayla ilgili istihbarî bilgi alması üzerine harekete geçmesi neticesinde bu girişimde başarısız olacaklarını düşünen kaçakçılar güzergâh değişikliğine gitmek zorunda kalmışlar. Kaçakçılar yeni rota olarak Adana’ya bağlı olan Karataş nahiyesini belirlemişlerdir. Nahiyeye çıkarılacak olan kaçak malların burada ikamet eden Hemavend Aşireti'nin Kürt mensuplarına satılması hedeflenmiştir. Elde edilen bulgu ve belgeler ışığında yürütülen takibat ve araştırma neticesinde satış işleminin gerçekleşmesi için ise Adana'da ikamet etmekte olan Numan Usta ile irtibata geçildiği tespit edilmiştir. Ayrıca kaçakçılığı yapacak kişilerin daha önceden keşif amaçlı sürekli şekilde Adana ile Karataş'a gidip geldikleri tespit edilmiştir. $\mathrm{Bu}$ kaçakçılarla ilgili yürütülen tahkikat neticesinde işbirlikçilerin Halep'te olduğunun anlaşılması üzerine Halep vilayetine telgraf çekilerek konun araştırılması ve bu gibi girişimlerin engellenmesi yönünde gerekli tedbirlerin alınması gerektiği ifade edilmiştir. Nitekim daha önce bu kaçakçılarla ilgili istihbarî bilgiler Halep valiliğinden gönderilmişti. Suçluların yakalanıp

\footnotetext{
15 İskenderun'a bağlı olan nahiyede yaşayan nüfusun çoğu Müslüman ahaliden oluşmaktadır (BOA, DH. ŞFR, 184/72, 22 Kasım 1895).

${ }^{16}$ Okka olarak da isimlendirilen Kıyye 400 dirheme tekabül etmektedir. Günümüzde ise 1.283 gramlık ağırlığa denk gelmektedir (Yurtsever, 2008, s. 142).
} 
yargılanması neticesinde Reji İdaresi ile Osmanlı İmparatorluğu'nun çıkarlarını zedeleyerek kayıt dışı ekonomi girişiminde bulunan Giritli Mustafa ile Numan Usta'nın ifadeleri alındıktan sonra karşı karşıya getirilerek yüzleștirilmelerine karar verilmiştir. Yüzleşmenin gerçekleşmesi neticesinde Adana bölgesinde yaşayan Hemavendlilerin bu iş ile alakaları olmadığı tespit edilmiştir. (BOA, DH. ŞFR, 311/24, 30 Eylül 1901).

\section{Sonuç}

Osmanlı İmparatorluğu'nun kuruluşundan itibaren var olan kaçakçıllk faaliyetleri özellikle asayiş sorunlarının artış göstermiş olduğu son dönemlerde daha da yaygın olarak görülmeye başlanmıştır. Bu durumun yaşandığ 1 alanlardan biri de Reji İdaresi'nin denetiminde olan tütün olmuştur. Reji İdaresi'nin 1883 yllında kurulmasıyla birlikte tütün alanında meydana gelen kayıt dışı ekonomi faaliyetleri doruk noktasına ulaşmıştır. Reji İdaresi'nin uygulamaları ve yürütmüş olduğu politikalara karşı doğal tepki olarak ortaya çıkan kaçakçılık sadece tüketiciler arasında değil üretici ve tüccarlar arasında da yaygınlık kazanmıştır. Reji İdaresi üretilen kaliteli tütünleri iç piyasa yerine dış piyasaya sürmesinden dolayı tüketiciler kaliteli tütünün ülkelerinde yetișmesine rağmen hem düșük kaliteli tütün tüketme hem de Reji İdaresi’nin belirlemiș olduğu yüksek fiyata düşük kalitede tütün almak zorunda bırakılmıştır. Reji İdaresi'nin bu gibi uygulamaları bölgede kaçakçılık faaliyetlerinin artmasina neden olmuştur. Üretmiş olduğu tütünü Reji İdaresi'ne düşük fiyata satmak istemeyen Anadolu köylüsü kadar, kaliteli tütün tüketmek isteyen tüketici de kaçakçllı̆̆ tek çare olarak görmüştür. İmparatorluk genelinde olduğu gibi kaçakçılık faaliyetlerin yaygın olarak görüldüğü yerlerden biri de tütün üretiminin yoğun olarak yapıldığı Adana vilayeti olmuştur. Adana vilayetinde tüketici ve üreticinin yanı sıra kayıt dışı ekonomi faaliyetlerinde aşiretlerin de rolü etkili olmuştur. Bölgede tütün kaçakçılığında bulunduğu iddia edilen aşiretlerden biri de Hemavend Aşireti olmuştur. Ancak Hemavendlilerin tütün kaçakçıllı̆ 1 yaptıklarına dair ileri sürülen görüşlerin asılsız olduğu tespit edilmiştir.

Hemavend Aşireti'nin bölgede tütün kaçakçlığı yaptığına dair ilk iddia 1889 yllında gerçekleşmiştir. Bu iddia Hemavend Aşireti'ne mensup 15 veya 20 kişilik grubun firar ederek Adana bölgesinde kaçakçılık ve eşkıyalık faaliyetlerinde bulundukları yönünde olmuştur. Bir diğer önemli iddia ise 1899 yılında gerçekleşmiştir. 150 veya 200 kişilik silahlı grubun Adana bölgesinde tütün kaçakçılığı yaparak Adana Reji İdaresi'nin gelirlerini ciddi oranda düşüren bir takım yasadışı işlere giriştiği tespit edilmiştir. Bu girişimde bulunan kaçakçıların Adana bölgesine yerleştirilmiş olan Hemavendli eski Surtaş nahiye müdürü Kake Abdullah Bey ile akrabaları olduğu iddia edilmiş̧ir. Ancak yapılan araştırma ve inceleme neticesinde Adana Reji İdaresi'nin gelirlerini \% 80 oranında azaltan kaçakçıllk faaliyetlerinin Hemavendliler tarafından değil de bölgede bulunan asi Çerkes ve Çeçen gruplar tarafindan gerçekleştirildiği tespit edilmiştir. Bölgede Hemavendliler ile ilgili bir diğer kaçakçılık iddiası ise 1903 yılında gerçekleşmiştir. Nikde adındaki Sömbekili olan süngerci ile Giritli Mustafa Befaki'nin denetimi altında bulunan bir kayık ile içerisinde yasaklanmıș olan kaçak silah ve barutun yanı sıra kaçak tütün İskenderun'a çıkarılmaya çalışılmıştır. Ancak kolluk kuvvetleri tarafından yapılan takibat neticesinde bunda başarılı olunmadığı tespit edilmiştir. İçerisinde kaçak malların bulunduğu kayığın Adana vilayetine bağlı Karataş nahiyesine çıkarılarak burada Numan Usta adındaki bir şahıs ile irtibata geçilmiştir. Kaçak silah ve tütünlerin bölgedeki Hemavendli Kürtlere satılmaya çalıșıldığına dair iddialar üzerine kolluk kuvvetlerinin kaçakçılara yönelik gerçekleştirdiği baskın neticesinde kaçakçılar kaçak mallarla birlikte yakalanmışlardır. Yapılan sorgulama neticesinde Hemavendlilerin kaçak mallarla bir bağlantısının olmadığ 1 tespit edilmiştir.

Adana bölgesine yerleştirilmiş olan Hemavend Aşireti'ne mensup şahısların kaçakçıllk yaptıklarıyla ilgili öne sürülen bu üç iddianın doğrudan doğruya Hemavendliler tarafından gerçekleştirildiğine dair önemli delilere ulaşılamamıştır. Kaldı ki yapılan araştırmalar neticesinde bölgeye gelen Hemavendlilerin çoğunun kadın ve çocuklardan oluştuğu tespit edilmiştir. Aileye mensup vatandaşlar arasında önde gelen isimlerden Kake Abdullah ve Mehmet Bey gibi isimlerin devletin önemli kurumlarında görevlendirildikleri tespit edilmiştir. Memurluk için durumu elverişli olmayıp tarım işi ile uğraşan kesime ise geçimlerini sağlayabilmeleri amacıyla işletmek için arazi tahsis edilmiştir. Hükümetin bölgeye yerleştirmiş olduğu aşiret mensuplarından önde gelenlerine memurluk vererek devlete bağlılıklarını arttırması, ziraat yapabilecek durumda olanlara geçimlerini sağlayabilmeleri amacıyla arazi ve tarım aletlerinin tahsis edilmesi ile çalışamayacak durumda olanlara ise maaş bağlamasıyla onların eşkıyalık ve kaçakçılık gibi bir takım yasadışı işlere karışmalarını önlemeyi hedeflemiştir. Nitekim yürütülen bu politikada da başarı elde edildiği tespit edilmiştir. 


\section{Kaynaklar}

Alan, G. (2014). 19. Yüzyılda Osmanlıda Sürgün Politikası Çerçevesinde Sürgün Kadınlar. Belleten Dergisi, $78(281), 245-272$.

Aslan, D. (2005), Dünyada ve Türkiye’de Tütün Kontrolünde Yeni Bir Dönem Başladı: Tütün Kontrolü Çerçeve Sözleşmesi. Sürekli Tıp Eğitimi Dergisi, 14(1), (2005), 1-24.

Aslıhan Özüdoğru, A. (2010). Adana'da Dokuma Sanayi Yapılarının Endüstri Mirası Kapsamında İncelenmesi. (Yayımlanmamış Yüksek Lisans Tezi). Çukurova Üniversitesi Fen Bilimleri Enstitüsü, Adana.

Aycan, A. (2017). Osmanlı'da Devlet-Aşiret İlişkileri: Hemvend Örneği (1876-1918). (Yayımlanmamış Yüksek

Lisans Tezi). Marmara Üniversitesi Türkiyat Araştırmaları Enstitüsü, İstanbul.

Aydın, H. (2019). Adana Vilayeti Salnamelerine Göre Kozan Livası. (Yayımlanmamış Yüksek Lisans Tezi).

Aksaray Üniversitesi Sosyal Bilimler Enstitüsü, Aksaray.

Balkan, İ. (2011). Yine Kolcular Döndü mü? Son Tütüncü Öldü mü?. İstanbul: IQ Kültür Sanat Yayınları.

Baydilli, K. (2007). Nizam-1 Cedid, Türkiye Diyanet Vakfi İslam Ansiklopedisi, (C. 33, 175-178. ss.). İstanbul.

Demir, İ., Demirbaş, U., Yıldırım, H. O. (1993). Musul-Kerkük İle İlgili Arşiv Belgeleri (1525-1919). Ankara:

T.C. Başbakanlık Devlet Arşivleri Genel Müdürlüğü Osmanlı Arşiv Daire Başkanlığı.

Demir, K. (2019). II. Meşrutiyet Dönemi Osmanlı Basınında Tütün Tarımı ve Reji Şirketi. Balıkesir Üniversitesi Sosyal Bilimler Enstitüsü Dergisi, 22(41), 419-446.

Demirci, S., Çabuk, F. (2015). Hemavend Kürt Aşireti'nin Musul Vilayeti ve Osmanl1-İran Sınır Boylarındaki Eşkıyalık Faaliyetlerine Dair Bir Değerlendirme. Hıstory Studıes Internatıonal Journal Of Hıstory, 7(3), 3959.

Dığıroğlu, F. (2007). Memalik-i Osmaniye Duhanları Müşterekü’l-Menfaa Reji Şirketi-Trabzon Reji İdaresi 1883-1914. İstanbul: Osmanlı Bankası Arşiv ve Araştırma Merkezi Yayınları.

Dığıroğlu, F. (2014). Selanik Ekonomisinde Unutulmuş Bir Alan: Tütün Üretimi, Ticareti ve Reji (1883-1912). Osmanlı Araştırmaları The Journal Of Ottoman Studies, XI(III), 227-272.

Efendi, P. (1997). Türkiye'nin Mali Tutsaklı̆̆ı, (Çev. Sencer, Muammer). İstanbul: May Yayınları.

Erkuş, H., Karagöz, K. (2009). Türkiye'de Kayıt Dışı Ekonomi ve Vergi Kaybının Tahmini. Maliye Dergisi, (156), 126-140.

Gündüz, A. (2010). Süleymaniye-Kuzey-Irak'ta Bir Şehir. Türk Diyanet Vakfi İslam Ansiklopedisi, (C. 38, 111113. ss.). İstanbul.

Gündüz, A. Y. (2012), Osmanlı Devleti’nin Ekonomi ve Dış Borç Politikası. Bingöl Üniversitesi Sosyal Bilimler Enstitüsü Dergisi, 2(2), 1-23.

Gürdamar, E. (2019). Cumhuriyet'in İlk Yıllarında Tütün Politikaları. (Yayımlanmamış Doktora Tezi). İnönü Üniversitesi Sosyal Bilimler Enstitüsü, Malatya.

Gökdemir, O. (1993). XIX. Yüzyıl Sonunda İzmir ve Çevresinde Tütün Kaçakçılığı. DEÜ Atatürk İlkeleri ve Inkılap Tarihi Enstitüsü Çăgdaş Türkiye Araştırmaları Dergisi, 1(3), 323-333.

Gökdemir, O. (1994). Aydın Vilayeti'nde Tütün Rejisi, (Yayımlanmamış Doktora Tezi). Dokuz Eylül Üniversitesi Atatürk İlkeleri ve İnkılap Tarihi Enstitüsü, İzmir.

Hanilçe, M. (2018). Orta Doğu'da Osmanlı Vilayet Gazetelerine Bir Örnek: Zevra Gazetesi (1869). Türk Basın Tarihi Uluslararası Sempozyumu, 1, 231-270.

Hasgül, S. (2016). Salnamelere Göre Adana Vilayeti’nin Demografik ve Kültürel Yapısı (Adana Merkez. Kozan, Cebel-i Bereket, İçel ve Mersin Sancă̆l). (Yayımlanmamış Yüksel Lisans Tezi). Mersin Üniversitesi Sosyal Bilimler Enstitüsü, Mersin.

Karamursal, Z. (1989). Osmanlı Mali Tarihi Hakkında Tetkikler. Ankara: Türk Tarih Kurumu Basımevi.

Kaş, P. (2012). Atatürk'ün Adana Ziyaretleri. (Yayımlanmamış Yüksek Lisans Tezi). Atatürk Üniversitesi Sosyal Bilimler Enstitüsü, Erzurum.

Kazgan, G. (2017). Tanzimat'tan 21. Yüzyıla Türkiye Ekonomisi. İstanbul: Bilgi Üniversitesi Yayınları.

Keskinkılıç, E. (1978). Bir Osmanlı Özelleştirme Modeli: Reji-Tütün İdaresi. Liberal Düşünce Dergisi, 4(14), 151-155.

Keskinkılıç, E. (1997). Osmanlı Düyun-ı Umumiye İdaresi’nin Kuruluşu, Gelişimi, Çalışması, Safhaları ve Osmanlı Devletine Etkileri. (Yayımlanmamış Doktora Tezi). Ankara Üniversitesi Sosyal Bilimler Enstitüsü, Ankara.

Konur Çakmak, N. (2019). Osmanlı'da Sanayileşme: Adana'da Fabrikalaşma Süreci (1864-1912). (Yayımlanmamış Yüksek Lisans Tezi). Mersin Üniversitesi Sosyal Bilimler Enstitüsü, Mersin.

Kurt, Y., Ünlü, E. (2014). Çukurova Tarihi'nin Kaynakları VI - 1572 Tarihli Sis (Kozan) Sancă̆ı Mufassal Tahrir Defteri. Ankara: Türk Tarih Kurumu Yayınları.

Kültüral, Z., Giannopoulos, A. (2021). Dr. Besim Ömer'in Kaleminden Tütün Kahve Çay. Konya: Palet Yayınları.

Ösen, S. (2015), Osmanlı Devleti'nde Tütün Kaçakçılarıyla Mücadele: Niğde Örneği. SÜTAD, (38), 49-68.

Özcan, M. (2011). Düyun-ı Umumiye İdaresi'nin Kurulmasl ve Osmanl İktisadı Üzerine Etkileri. (Yayımlanmamış Yüksek Lisans Tezi). Marmara Üniversitesi Sosyal Bilimler Enstitüsü, İstanbul. 
Pamuk, Ş. (1984). Osmanlı Ekonomisi ve Dünya Kapitalizmi (1820-1913). Ankara: Yurt Yayınları.

Pamuk, Ş. (2018). Osmanlı Ekonomisinde Bağımlılık ve Büyüme (1820-1913). İstanbul: Türkiye İş Bankası Kültür Yayınları.

Pamuk, Ş. (2018). Osmanlı Ekonomisi ve Kurumları. İstanbul: Türkiye İş Bankası Kültür Yayınları.

Sezen, T. (2006). Osmanlı Yer Adları (Alfabetik Sirayla). Ankara: T.C. Başbakanlık Devlet Arşivleri Genel Müdürlüğü Yayınları.

Soyluer, S. (2018). Tüfekhane-i Amire’yi Mamur Kılmak: Osmanlı Tüfek İmalatında Avrupalı Uzmanların Rolü. Osmanlı Araştırmaları The Journal Of Ottoman Studies, 1(2), 267-309.

Şahin, İ. (2006). Nahiye, Türkiye Diyanet Vakfi Islam Ansiklopedisi, (C. 32, 306-308. ss.). İstanbul.

Telci, C. (2000). Bir Osmanlı Aydınının Adana İzlenimleri (Şerafeddin Mağmumi 1870-1927). Efsaneden Tarihe, Tarihten Bugüne Adana: Köprübaşı, (Haz. Erman Artun-M. Sabri Koz). İstanbul: Yapı Kredi Yayınları.

Üner, Mehmet E. (2011). Osmanlı İktisat Tarihi. Şanlıurfa: Urfa Sembol Yayınları.

Vedat, E. (1994). Osmanlı Imparatorluğu’nun İktisadi Şartları Hakkında Bir Tetkik. Ankara: Türk Tarih Kurumu Basimevi.

Yaman Öztürk, M., Keskin Ertürk, N. (2013). Tütün Sektöründe Yabancı Yatırım: Reji Deneyimi Işı̆̆ında Bugünü Anlamak. Çalışma ve Toplum Dergisi, 2, 98.

Yılgür, E. (2015). Roman Tütün İşçileri, İstanbul: Ayrıntı Yayınları.

Yurtoğlu, N. (2018), Türkiye Cumhuriyeti'nde Tütün Tekeli ve Sigara Fabrikalarının Tarihsel Gelişimi (19231950). Akademik Tarih ve Düşünce Dergisi, 5(17), 81-116.

Yurtsever, C. Z. (1981). Kadirli Tarihi (Kadirli Türkmenlerinin Soy, Kültür ve Ekonomik Bünyesinin Tarih Felsefesi Metoduyla Incelenmesi). İstanbul: Alper Yayınları.

Yurtsever, C. Z. (2008). Payas Tarihi. Adana: Payas Belediyesi Kültür Yayınları.

Yurtsever, C. Z. (2010). Kozan Tarihi. Adana: Çukurovalı Yayınları.

Yurtsever, C. Z. (2017). Hatıralar Canlanırsa Tarih Seslenir Adana Şehir Tarihi. Adana: Ekrem Matbaası.

Adana Vilayet Salnamesi, Hicri 1308.

Adana Vilayet Salnamesi, Hicri 1309.

Adana Vilayet Salnamesi, Hicri 1320.

Adana Vilayet Salnamesi, Hicri 1312.

Adana Vilayet Salnamesi, Hicri 1318.

\section{Arşiv Kaynakları}

Türkiye Cumhuriyeti Cumhurbaşkanlığı Devlet Arşivleri Başkanlı̆̆ Osmanlı Arşivi (BOA)

BOA, A.) MKT. MHM, 560/6, 27 Temmuz 1893.

BOA, A.) DVN. MKL, 82/2, 19 Subat 1912.

BOA, BEO, 1239/92902, 10 Aralık 1898.

BOA, BEO, 4219/316355, 4 Ekim 1913.

BOA, BEO, 1165/87359, 27 Temmuz 1898.

BOA, DH, 1474/16, 3 Ocak 1888.

BOA, DH. MKT, 1528/112, 4 Ağustos 1888.

BOA, DH. MKT, 1796/29, 29 Aralık 1890.

BOA, DH. MKT, 2428/103, 16 Kasim 1900.

BOA, DH. MKT, 1700/5, 17 Şubat 1890.

BOA, DH. MKT, 1825/80, 5 Nisan 1891.

BOA, DH. MKT, 2407/8, 25 Mart 1887.

BOA, DH. MKT, 2120/28, 19 Ekim 1898.

BOA, DH. MKT, 2152/30, 24 Aralık 1898.

BOA, DH. MKT, 1568/36, 25 Kasım 1888.

BOA, DH. MKT, 1570/7, 1 Aralık 1888.

BOA, DH. MKT, 1547/13, 25 Eylül 1888.

BOA, DH. MKT, 1623/18, 14 Mayis 1888.

BOA, DH. MKT, 1617/128, 20 Nisan 1889.

BOA, DH. MKT, 1973/16, 18 Temmuz 1892.

BOA, DH. MKT, 1878/85, 15 Ekim 1891.

BOA, DH. MKT, 1894/15, 26 Kasım 1891.

BOA, DH. MKT, 1936/46, 25 Mart 1892.

BOA, DH. MKT, 1904/2, 22 Aralık 1891.

BOA, DH. MKT, 1884/15, 31 Ekim 1891.

BOA, DH. MKT, 1779/111, 10 Kasim 1890.

BOA, DH. MKT, 1772/124, 18 Ekim 1890. 
BOA, DH. MKT, 2269/92, 13 Kasım 1899.

BOA, DH. MKT, 2292/89, 2 Ocak 1900.

BOA, DH. MKT, 311/7, 27 Eylül 1901.

BOA, DH. MKT. 311/24, 30 Eylül 1901.

BOA, DH. MKT, 35/46, 11 Mayıs 1893.

BOA, DH. MKT, 1936/46, 25 Mart 1892.

BOA, DH. MKT, 380/15, 30 May1s 1895.

BOA, DH. MKT, 1446/29, 12 Eylül 1887.

BOA, DH. ŞFR, 184/72, 22 Kasım 1895.

BOA, HR. İ, 290/50, 10 Aralık 1879.

BOA, HR. İD, 304/31, 26 Aralık 1882.

BOA, HR. ID, 304/33, 26 Aralık 1882.

BOA, HR. ID, 304/34, 26 Aralık 1882.

BOA, HR. HMŞ. İŞO, 166/31, 10 Şubat 1884).

BOA, İ. MMS, 92/3888, 4 Ağustos 1887.

BOA, MV, 34/59, 8 Ağustos 1888.

BOA, MV, 165/11, 19 Mayıs 1912.

BOA, MV, 34/59, 8 Ağustos 1888.

BOA, MV, 74/49, 15 May1s 1893.

BOA, Y. A. RES, 4/70, 22 Kasim 1879.

BOA, Y. A. HUS, 184/106, 29 Ekim 1885.

BOA, Y. PRK. KOM, 6/25, 10 Ocak 1888. 